\title{
Natural killer cells for cancer immunotherapy: pluripotent stem cells-derived NK cells as an immunotherapeutic perspective
}

\section{Cristina Eguizabal ${ }^{1}$, Olatz Zenarruzabeitia ${ }^{2}$, Jorge Monge ${ }^{1}$, Silvia Santos ${ }^{1}$, Miguel Angel Vesga ${ }^{1}$, Natalia Maruri ${ }^{3}$, Arantza Arrieta ${ }^{3}$, Marta Riñón ${ }^{3}$, Estibaliz Tamayo-Orbegozo ${ }^{3}$, Laura Amo ${ }^{3}$, Susana Larrucea ${ }^{3}$ and Francisco Borrego ${ }^{2,4}$ *}

\author{
'Basque Center for Transfusion and Human Tissues, Galdakao, Spain \\ ${ }^{2}$ Immunopathology Group, BioCruces Health Research Institute, Barakaldo, Spain \\ ${ }^{3}$ Regulation of the Immune System Group, BioCruces Health Research Institute, Barakaldo, Spain \\ ${ }^{4}$ Ikerbasque, Basque Foundation for Science, Bilbao, Spain
}

Edited by:

Angela Santoni, University Sapienza

of Rome, Italy

Reviewed by:

Evelyn Ullrich, Goethe University

Frankfurt, Germany

Chiara Romagnani, Deutsches

Rheuma Forschungszentrum,

Germany

*Correspondence:

Francisco Borrego, Immunopathology Group, BioCruces Health Research

Institute, Plaza de Cruces s/n,

Barakaldo 48903, Spain

e-mail: francisco.borregorabasco@

osakidetza.net;

pacoborregorabasco@gmail.com
Natural killer (NK) cells play an essential role in the fight against tumor development. Over the last years, the progress made in the NK-cell biology field and in deciphering how NK-cell function is regulated, is driving efforts to utilize NK-cell-based immunotherapy as a promising approach for the treatment of malignant diseases. Therapies involving NK cells may be accomplished by activating and expanding endogenous NK cells by means of cytokine treatment or by transferring exogenous cells by adoptive cell therapy and/or by hematopoietic stem cell transplantation. NK cells that are suitable for adoptive cell therapy can be derived from different sources, including ex vivo expansion of autologous NK cells, unstimulated or expanded allogeneic NK cells from peripheral blood, derived from CD34+ hematopoietic progenitors from peripheral blood and umbilical cord blood, and NK-cell lines. Besides, genetically modified NK cells expressing chimeric antigen receptors or cytokines genes may also have a relevant future as therapeutic tools. Recently, it has been described the derivation of large numbers of functional and mature NK cells from pluripotent stem cells, both embryonic stem cells and induced pluripotent stem cells, which adds another tool to the expanding NK-cell-based cancer immunotherapy arsenal.

Keywords: NK cells, adoptive cell therapy, cancer immunotherapy, hematopoietic stem cell transplantation, pluripotent stem cells, embryonic stem cells, induced pluripotent stem cells

\section{INTRODUCTION}

Natural killer (NK) cells are innate lymphoid cells that have an important role in regulating the defenses to viral infections and cancer development (1-6). The vast majority of circulating mature human NK cells in healthy donors are identified as CD3-CD56+ lymphocytes. Approximately, 90\% of peripheral blood and spleen NK cells belong to the $\mathrm{CD} 56^{\mathrm{dim}} \mathrm{CD} 16^{+}$subset, which is characterized by a potent cytotoxic activity after interaction with target cells. On the other hand, NK cells on lymph nodes and tonsils are mostly $\mathrm{CD} 56^{\text {bright }} \mathrm{CD} 16^{\mathrm{dim} /-}$ and have poor cytotoxic activity, while they produce very significant amounts of cytokines, such as interferon (IFN) $-\gamma$, in response to IL-12, IL-15, IL-18, and type I IFN stimulation $(7,8)$. NK cells are equipped with an array of activating and inhibitory receptors that stimulate or dampen NK-cell activity, respectively. Inhibitory receptors include the MHC class I ligands killer-cell immunoglobulin-like receptors (KIRs) with two or three extracellular immunoglobulin domains and long cytoplasmic tail (KIR2DL and KIR3DL), leukocyte immunoglobulin-like receptor subfamily member 1 (LILRB1) and CD94/NKG2A, and other inhibitory receptors such as CD300a, leukocyte-associated immunoglobulin-like receptor1 (LAIR-1), and others. Activating receptors include cytokine and chemokine receptors, and those that interact with ligands expressed on target cells. The latter include, among others, the natural cytotoxicity receptors or NCRs (NKp30, NKp44, and NKp46), NKG2D, KIR with short cytoplasmic tail (KIR2DS and KIR3DS), CD94/NKG2C, CD244, and DNAM-1. In addition, NK cells also express the death ligands FasL and TRAIL that after interaction with death receptors Fas and DR5, respectively, initiate a signaling cascade resulting in apoptosis of the target cell. Finally, NK cells express FcyRIIIA or CD16, the receptor that exerts antibody-dependent cell-mediated cytotoxicity (ADCC) $(4,9-13)$.

Natural killer-cell effector functions are dynamically regulated, and the killing or sparing of target cells depends on the integration of distinct signals that emanate from NK-cell receptors after their interaction with ligands expressed on target cells. NK cells spare healthy cells that express MHC class I molecules and low amounts of stress-induced self-molecules, while they kill target cells that up-regulate stress-induced self-molecules and/or down-regulate MHC class I molecules $(4,5,11,12)$. The latter are common features of virus-infected cells and tumors $(14,15)$. The investigation of NK-cell reactivity has revealed the basis of tumor recognition, and several lines of evidence have shown that 
NK cells have a critical role in host immunity against cancer (2, 16-19). In response, tumors have evolved mechanisms to escape control from NK cells, such as the modulation of NK-cell receptorligand expression patterns and the secretion of immunoregulatory molecules or immunosuppressive modulators such as IDO, PGE2, and TGF- $\beta$, that down-regulate NK-cell effector functions (20-24).

So far, all the amassed knowledge has driven efforts to harness NK cells with the purpose to improve the therapeutic options for patients living with cancer. Indeed, NK-cellbased adoptive cell immunotherapy is emerging as a promising approach for treatment of many cancers (25-27). Therapeutic NK cells can be derived from different sources, including peripheral blood or cord blood cells, adult hematopoietic stem cells (HSCs), embryonic stem cells (ESCs), or induced pluripotent stem cells (iPSCs).

\section{NK-CELL-BASED IMIMUNOTHERAPY}

Given the role that NK cells have in the defense against tumor development, the therapeutic use of NK cells to treat malignancies is currently being exploited. It is very well established that NK cells have a very important role in the anti-tumor effect of therapeutic antibodies that use ADCC as a mechanism of action (28-31). In addition, in the clinical context, several approaches have been proposed for NK-cell-based immunotherapy, including in vivo cytokine-mediated expansion of endogenous NK cells, as well as the adoptive transfer of unmodified or ex vivo activated and expanded autologous and allogeneic NK cells, and some NK-cell lines, such as NK-92 (26, 32-41). Furthermore, genetically modified NK cells expressing cytokine genes or chimeric antigen receptor (CAR), are being studied for potential use in the clinic (26, 42-44). In clinical trials, NK-cell infusions alone or in the course of allogeneic hematopoietic stem cell transplantation (HSCT), are being tested as therapy for refractory tumors. In addition, they are also tested as consolidation immunotherapy, which could be an important therapeutic tool in high risk hematological malignancies during the remission phase after chemotherapy, and when allogeneic HSCT is not indicated due to its high degree of toxicity $(45,46)$.

Early studies were aimed to in vivo expand endogenous NK cells and to improve their anti-tumor activity by administering systemic cytokines, such as IL-2, into patients (47-49). Other strategies included the ex vivo activation and expansion of autologous NK cells, following their adoptive transfer into the patients in combination with IL-2 (32, 50-53). These approaches offered poor clinical outcomes due to high toxicity of IL-2 (54). Moreover, this cytokine promoted the expansion not only of NK cells but also of regulatory $\mathrm{T}$ (Treg) cells, therefore dampening NK cells effector functions (55). Others have assessed the effects of low-dose IL-2 administration and IL-2 boluses on NK-cell activation after autologous HSCT $(39,56)$. Whereas IL-2 significantly expanded the number of circulating NK cells in vivo, these NK cells did not exhibit maximal cytotoxic potential as determined by in vitro assays (39). In addition, although the infusion of IL-2-activated NK-cell-enriched populations or intravenous IL2 infusions combined with subcutaneous IL-2 augmented in vivo the NK-cell function, there was a lack of consistent clinical efficacy of autologous NK-cell-based therapy in patients with lymphoma and breast cancer when compared with cohorts of matched controls (56).

Although relatively safe, the lack of significant efficacy of therapy with autologous $\mathrm{NK}$ cells could be due to the interaction of MHC class I molecules expressed on cancer cells that, after their interaction with $\mathrm{MHC}$ class I-specific inhibitory receptors on NK cells, suppress their activation (4, 10-12). Specifically, since human NK cells are regulated by KIRs that interact with specific HLA class I molecules, it is expected that in HLA-nonidentical transplantation where the recipients lack the class I epitope specific for the donor's inhibitory KIRs (i.e., receptorligand mismatch), donor NK cells will be not inhibited, leading to a better prognosis due to a decreased risk of relapse. In fact, clinical data have shown that haploidentical KIR ligand-mismatched NK cells play a very important role as anti-leukemia effector cells in the haploidentical $\mathrm{T}$ cell-depleted transplantation settings $(57,58)$. Several publications have revealed that patients with acute myeloid leukemia (AML) are significantly more protected against leukemia relapse when they receive a transplant from NK alloreactive donors (38, 57-62). Furthermore, several strategies using adoptively transferred allogeneic NK cells have been shown to be successful for cancer immunotherapy, including those against leukemia and solid tumors (36, 63-66). Table 1 depicts a summary of completed clinical trials that have used infusion of allogeneic NK cells. Importantly, the infusion of allogeneic NK cells has also been demonstrated to be a safe therapy with low toxicity (38). Prominently, there are also clinical studies that have confirmed that infusion of donor-recipient inhibitory KIR-HLA-mismatched NK cells, following mild conditioning, is well tolerated by pediatric patients, which indicates that this is a promising novel therapy for reducing the risk of relapse in children with tumors $(45,67)$.

Using NK-cell lines as source for the treatment of cancer may also be beneficial. Specifically, the use of NK-92 cell line has been demonstrated to be a safe therapy with anti-tumor effects $(41,68$, 69). In fact, the FDA has approved the testing of NK-92 infusions in patients with advanced solid tumors (68).

The successful use in the clinic of CAR-expressing T cells in the treatment of hematological malignancies has prompted the development of other CAR-expressing cytotoxic cells. In this context, preclinical studies are being carried out investigating the targeting of tumors using CAR-redirected NK cells (43, 70-79). Although the majority of these studies have been performed against targets of hematological origin, it has also been described as promising results with NK cells transduced with CARs specific for antigens expressed on solid tumors $(75,78,79)$. Mostly, all these studies have been done with the NK-92 cell line transduced with the specific CAR, although in vitro stimulated NK cells from healthy donors and pediatric leukemia patients have also been used (70).

In order to successfully use NK-cell infusions in the clinical setting, a sufficient number of highly enriched NK cells must be obtained. Allogeneic unmodified NK cells can be adoptively transferred after leukapheresis products are $\mathrm{T}$ cell-depleted, in 
Table 1 | Selected completed clinical trials that have used infusion of allogeneic NK cells in https://clinicaltrials.gov.

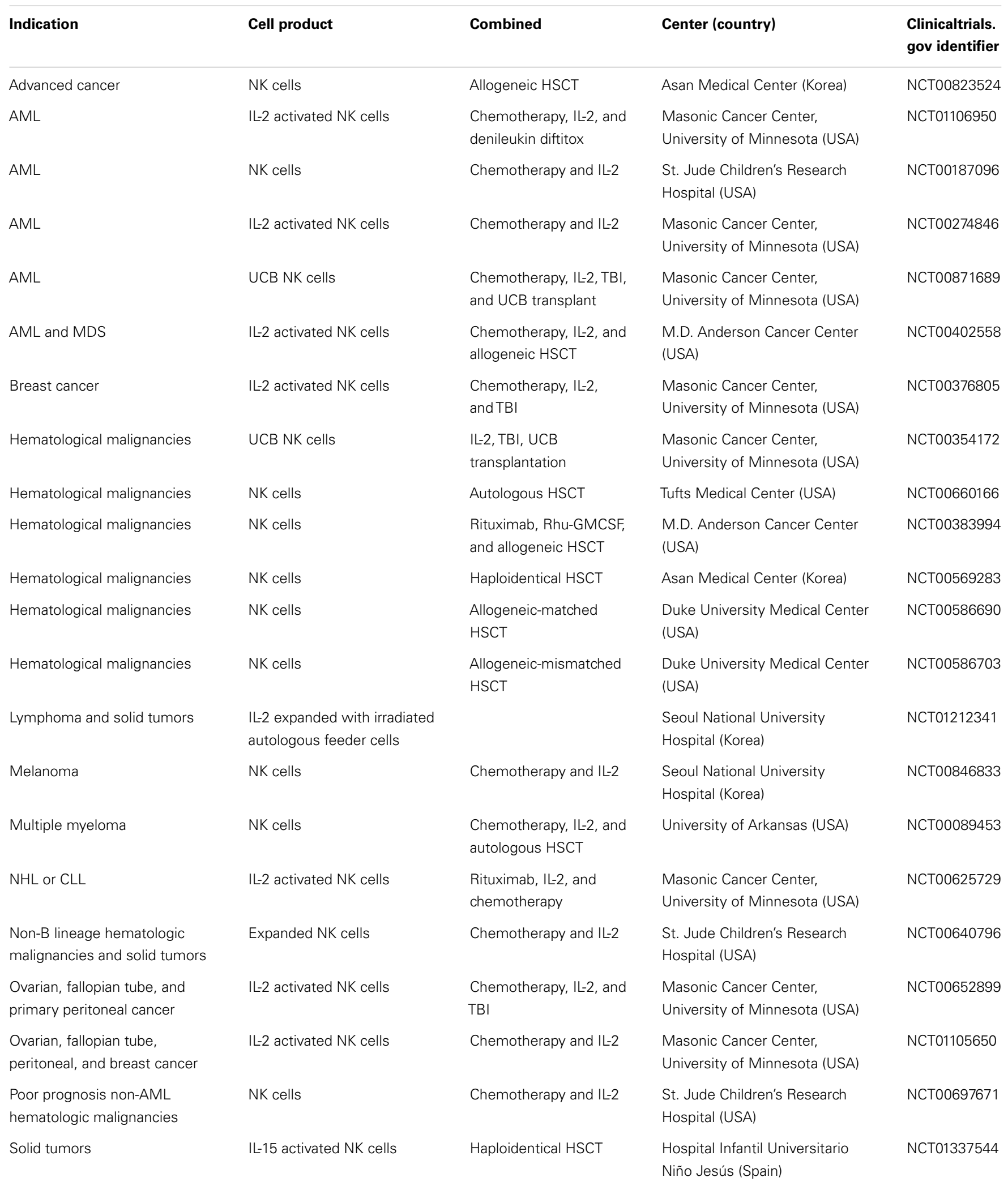

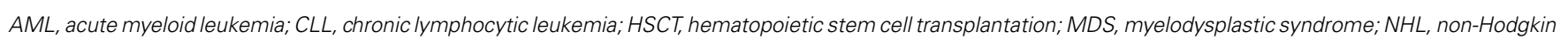
Iymphoma; TBI, total body irradiation; UCB, umbilical cord blood. 
combination with B cell depletion and/or NK-cell enrichment (67, $80,81)$. In the context of allogeneic HSCT, the transfer of unmodified NK cells or CD3/CD19-depleted grafts results in recovery of elevated NK-cell numbers, which can also expand in vivo $(67,81$, 82). In the absence of HSCT, successful NK-cell expansion in vivo is achieved by the administration of IL-2 in combination with products that deplete Treg cells (80).

Various methods for large-scale and clinical-grade ex vivo NKcell expansion have been reported with this aim (83-92). Due to the advantage of aseptic conditions in a closed system, peripheral blood mononuclear cells (PBMCs) collected by leukapheresis are frequently used as source for goods manufacturing practice (GMP)-compliant expansion of NK cells $(84,85,87)$. In general, the expansion of allogeneic NK cells involves two sequential steps. The first consists in the magnetic depletion of $\mathrm{CD} 3+\mathrm{T}$ lymphocytes, followed by a second step of enrichment of CD56+ NK cells $(83,85,87,90)$. To expand the purified NK cells, they are cultured with cytokines, such as IL-2, IL-12, IL-15, and IL-21 (84, 85, 87, $93,94)$. In order to further encourage NK-cell proliferation, several authors have used irradiated feeder cells in the culture, such as PBMCs, Epstein-Barr virus-transformed lymphoblastoid cell lines or engineered leukemic cell lines $(83,86,90,95)$. Irradiated feeder cells stimulate NK cells through both humoral factors and direct cell-to-cell contact. However, there are technical disadvantages by using supportive feeder cell lines that could lead to problems with the regulatory agencies.

$\mathrm{CD} 34+$ hematopoietic progenitors from umbilical cord blood (UCB) are also being considered as a source for the production of a large number of allogeneic NK cells $(89,91,92,96,97)$. Some groups have described different protocols for the generation of NK cells from CD34+ cells using coculture systems with stromal cell lines and a combination of cytokines that promote the development of NK cells $(88,97,98)$. Very importantly, other authors have been able to generate large numbers of UCB CD34+ cellsderived NK-cell products for adoptive immunotherapy in closed, large-scale bioreactors, and stromal cell lines free, for the use in future clinical trials $(91,92)$. These NK cells have been shown to efficiently target bone marrow-residing human leukemia cells in preclinical studies (96). It is important to investigate, which cytokines added to these cultures favors the generation of higher numbers of mature NK cells with enhanced effector functions. For example, it has been shown that IL-12 directs human NK-cell differentiation ex vivo from CD34+ cord blood precursors toward more mature NK cells with improved properties (93).

Obtaining a significant number of pure and functional NK cells is a critical factor for NK-cell-based immunotherapy. Several authors have shown the efficient generation of a large number of functional and mature NK cells from human embryonic stem cells (hESCs) and iPSCs, suggesting that the clinical use of these NK cells may be a reasonable expectation for the future of cancer immunotherapy (99-104).

\section{PLURIPOTENT STEM CELLS: ESCs AND iPSCs}

Since the derivation of hESCs, more than 20 years ago by Thomson et al., numerous groups have successfully differentiated these cells into fully mature and functional cells from each germ layer (105). Shortly, after the original derivation of hESCs, various groups demonstrated the hematopoietic development using an in vitro model and defined conditions (103, 104, 106-111).

One of the scientific breakthroughs of the last years has been to determine that pluripotency can be recovered by several differentiated somatic cell types through the overexpression of just four transcription factors (OCT4, SOX2, cMYC, and KLF4) (112-114). These cells are named iPSCs. Depending on the donor's somatic cell type, the reprograming process is accomplished with different efficiency. Just 7-12 days are required to reprogram mouse embryonic fibroblasts (MEFs) (115), whereas human foreskin fibroblasts take 20-25 days, using retrovirus technology in both cases (116). Compared with fibroblasts, human keratinocytes can be reprogramed 100 times more efficiently and twofold faster (116). After choosing the target donor somatic cell type, it is necessary to select a cocktail of reprograming factors that usually are the four above mentioned. In few situations less than four factors are needed, such as in the case of cord blood CD133+ cells and keratinocytes (117). Through the reprograming process, the chromatin remodeling plays an essential role in the procurement of pluripotency. So far, it has been described that the use of some chemical compounds is able to alter the DNA methylation and induce chromatin remodeling that results in an improvement of the reprograming process. For example, treatment with DNA methytransferase inhibitor (5' azacytidine) and histone deacetylase inhibitors (SAHA, TSA, and VPA) improves reprograming efficiency in MEFs. Also, during the reprograming process, it is important to maintain the pluripotency state. This can be achieved by using compounds that inhibit glycogen synthase kinase 3, lysine-specific demethylase 1, or G9a (118-122). Once iPSCs are generated, they have the capability to differentiate toward ectodermal, mesodermal, endodermal, and germ cells. This is achieved by the addition to the culture media of some growth factors and several compounds that provide specific signals allowing iPSCs to differentiate in the cell type of interest (123).

Another important issue during the reprograming process is the method for the delivery of the transcription factors into the somatic cells. Currently, there are integrative delivery systems (retrovirus, lentivirus, linear DNA, and piggyBac transposon) and non-integrative systems (adenovirus, Sendai viral vectors, episomal vectors, synthetic mRNA, and proteins) $(123,124)$. The choice of one or another system will depend on the final use of the humaninduced pluripotent stem cells (hiPSCs). For research purposes, the usual methods are the integrative systems, whereas if hiPSCs are intended for future clinical use, the non-integrative methods should be more appropriated.

\section{GENERATION OF NK CELLS FROM hESCs AND hiPSCs}

Pluripotent stem cells (PSCs) are an important advance in stem cell research, as they allow researchers to obtain stem cells, which, in addition to be very useful tools for research, they may have therapeutic uses. Because hiPSCs are developed from a patient's own somatic cells, it is believed that hiPSCs-based therapy would be very poorly or non-immunogenic, whereas hESCs are not (125128). The use of these cells provides an accessible, genetically tractable, and homogenous starting cell population to efficiently study human blood cell development among others (100, 103, 108, 111, 129). hESCs and hiPSCs can provide important starting 
cell populations to develop new cell-based therapies that have the potential to treat both malignant and non-malignant diseases. The clinical applications of this type of cell-based therapy depend on the thoroughly understanding of the normal development and physiology of the PSCs and of the desired "final" cell population. Several groups have already demonstrated the ability of hESC and hiPSC-derived hematopoietic progenitor cells to produce functional NK cells that, hypothetically at least, could serve as a "universal" source of anti-tumor lymphocytes for cancer immunotherapy (99-104, 130, 131) (Figure 1). In addition, hiPSCs, which can be reliably engineered in vitro, provide an important new model system to study human NK-cell development, as well as a model for NK-cell deficiency and diseases with significant defects on NK-cell functions (108).

Generating CD34+ hematopoietic precursors is the first important step in the specific hematopoietic lineage differentiating protocols from hESCs and hiPSCs. The initial protocols achieved to obtain up to $20 \%$ of CD34+ cells by coculturing the hESCs with the OP9 mouse bone marrow stromal cells (111). Other groups obtained similar results using the S17 or M210B4 mouse bone marrow stromal cell lines, and they were able to in vitro generate CD34+CD45- and CD34+CD45+ precursors $(104,131,132)$. It has been described that hESCs-derived CD34+CD45+ cells contain more hematopoietic progenitors, and consequently are more suitable for the NK-cell differentiation when compared with the CD34+CD45- population (104). Usually, after the generation of hESCs- and hiPSCs-derived CD34+ hematopoietic precursors, these are sorted and subsequently cultured under conditions that favor the development of NK cells. For example, sorted hESCs-derived CD34+ cells were placed in culture with the murine fetal liver-derived AFT024 stromal cell line as feeder cells in medium supplemented with IL-15, IL-3, IL-7, SCF, and fms-like tyrosine kinase receptor-3 ligand (Flt3L) (104). At the end of the culture process, after 30 days, NK cells expressed maturation markers including KIRs, CD94/NKG2A, NCRs, and CD16 (104). In addition, these cells could lyse malignant cells by both direct cell-mediated cytotoxicity and ADCC. On the other hand, Knorr et al. have also proved the trafficking of hESC-derived NK cells to K562 tumor cells engrafted in sublethally irradiated mice for 4 days before NK-cell injection (130).

Other approach for the generation of CD34+ hematopoietic precursors in vitro is to differentiate both types of PSCs by

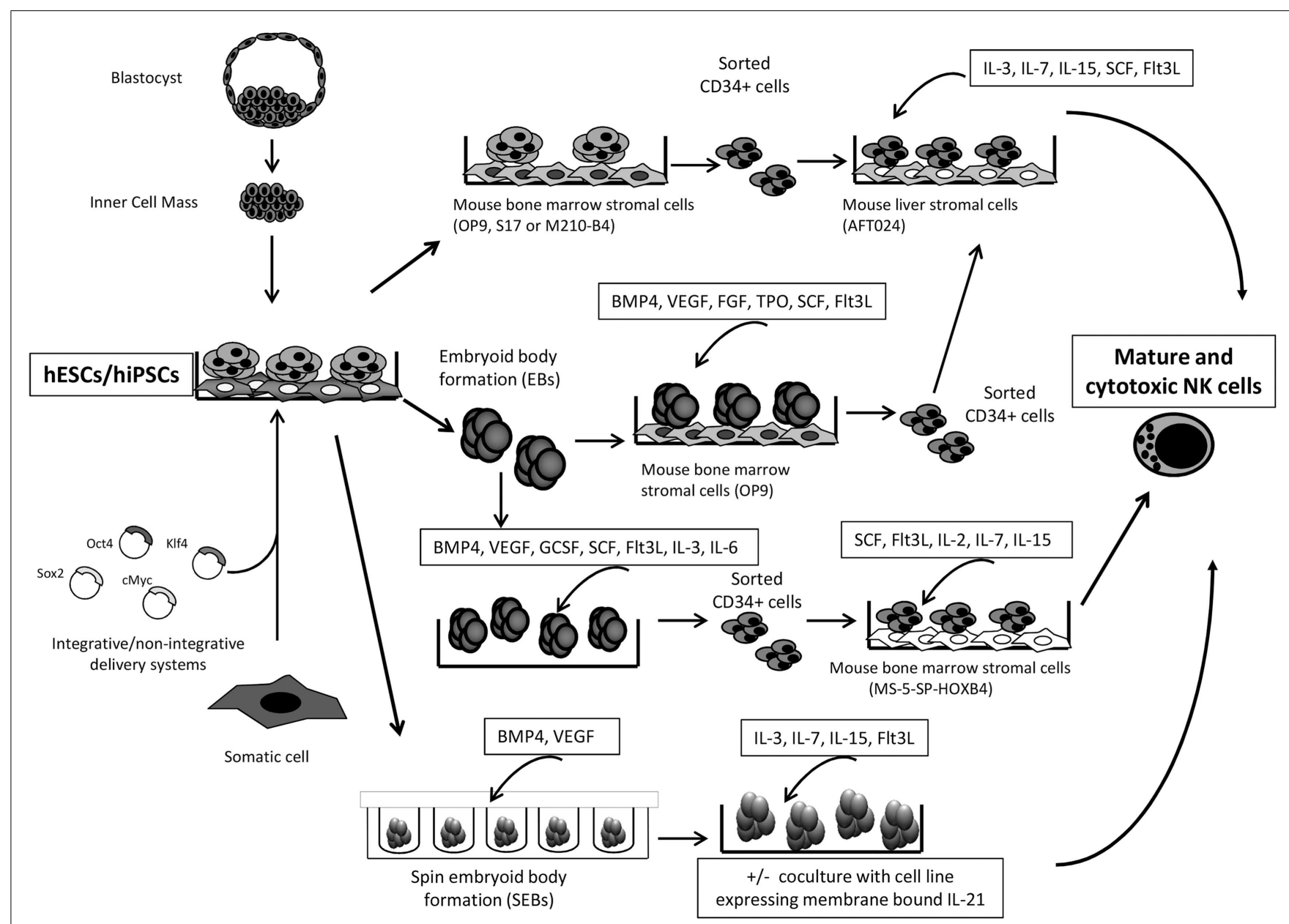

FIGURE 1 | Schematic representation for the generation of human ESC/iPSC-derived NK cells is shown. Summary of several protocols described in Ref. $(100,101,104,111,129-132)$. 
embryoid body (EB) assays followed by a coculture system with the OP9 stromal cell line and a cocktail of cytokines, such as BMP4, VEGF, SCF, FGF, TPO, and Flt3L (129, 133). EBs are threedimensional aggregates of PSCs, which resembles the embryonic development, including the differentiation toward cells of the hematopoietic lineage. Knorr and colleagues have used a refined method of the EBs assay, termed spin EBs, in the presence of BMP4 and VEGF and, after a period of 11 days of spin EB differentiation, they add IL-3, IL-7, IL-15, and Flt3L, that favors the development of NK cells $(100,130)$.

Other important factor for the in vitro differentiation of NK cells from PSCs is the role of the HOXB4 homeoprotein. Larbi et al. have described that HOXB4 delivery promotes the enrichment and expansion of EB-derived hematopoietic precursors that could differentiate into fully mature and functional NK cells (101). HOXB4 protein, in combination with stromal cells, has an important role in the development of NK cells from hESCs, suggesting the potential use of this protein for NK-cell enrichment from PSCs.

A step forward is the clinical-scale production of NK cells derived from PSCs for future cancer immunotherapy applications. Kaufman's group has improved the method for the clinical-scale generation of NK cells. They used a two-stage culture system to efficiently generate NK cells from hESCs and iPSCs in the absence of cell sorting and without the need for xenogeneic stromal cells. As mentioned above, the method is based on the combination of spin EB formation using defined conditions and membranebound interleukin 21-expressing artificial antigen-presenting cells that allow the production of mature and functional NK cells from several different hESC and iPSC lines. They are able to generate enough cytotoxic and mature NK cells to treat a single patient starting from fewer than 250,000 input hESCs/iPSCs that could be maintained and continuously expanded for at least 2 months (100).

\section{FUTURE DIRECTIONS}

Adoptive immunotherapy with NK-cell infusions is currently used in patients with high risk of relapse after $\operatorname{HSCT}(34,38,67)$. Even though preliminary results are encouraging, still critical issues remain unanswered, such as the characterization of standardized protocols for GMP-compliant production of clinical-grade NK cells. Apart from that, with continued advances in the stem cell field, it is likely that hPSC-derived NK cells will relatively soon be able to be efficiently derived on a patient-specific basis. Actually, hESC and hiPSC-derived NK cells express activating and inhibitory receptors similar to NK cells isolated from adult peripheral blood $(100,104,108,130)$. The hESC-derived NK cells are also highly efficient at direct cell-mediated cytotoxicity and ADCC, as well as cytokine (IFN- $\gamma$ ) production. And importantly, stromal cells-free protocols have successfully been described $(100,130)$. It is clear that hiPSC-derived NK cells provide a genetically manageable system to study human NK-cell development and function. In addition, these NK cells could provide an important source of lymphocytes for cancer therapy. There are several and serious obstacles to be overcome before PSC-derived NK cells can be considered for cancer immunotherapy. Safe methods for hiPSC generation and high reprograming efficacy are of the highest importance. Furthermore, the irreversible nature of hPSC-based therapy requires special precautions to be taken in any clinical trial. We have to be realistic and accept that multiple technical, safety, and regulatory obstacles are in the way for successful translation of hPSC-derived NK cells into the clinic. But hopefully, in a not so far future, all these hurdles will be surmounted and the use of hPSCs-based cancer therapies will be a reality.

\section{ACKNOWLEDGMENTS}

This work was supported by the Health Department, Basque Government (Grant 2013111034) and SAIOTEK, Basque Government (Grant SAIO13-PE13BF006).

\section{REFERENCES}

1. Lee SH, Miyagi T, Biron CA. Keeping NK cells in highly regulated antiviral warfare. Trends Immunol (2007) 28:252-9. doi:10.1016/j.it.2007.04.001

2. Marcus A, Gowen BG, Thompson TW, Iannello A, Ardolino M, Deng W, et al. Recognition of tumors by the innate immune system and natural killer cells. Adv Immunol (2014) 122:91-128. doi:10.1016/B978-0-12-800267-4.00003-1

3. Orange JS. Natural killer cell deficiency. J Allergy Clin Immunol (2013) 132:515-25. doi:10.1016/j.jaci.2013.07.020 quiz 526,

4. Vivier E, Raulet DH, Moretta A, Caligiuri MA, Zitvogel L, Lanier LL, et al. Innate or adaptive immunity? The example of natural killer cells. Science (2011) 331:44-9. doi:10.1126/science.1198687

5. Vivier E, Tomasello E, Baratin M, Walzer T, Ugolini S. Functions of natural killer cells. Nat Immunol (2008) 9:503-10. doi:10.1038/ni1582

6. Vivier E, Ugolini S, Blaise D, Chabannon C, Brossay L. Targeting natural killer cells and natural killer T cells in cancer. Nat Rev Immunol (2012) 12:239-52. doi:10.1038/nri3174

7. Caligiuri MA. Human natural killer cells. Blood (2008) 112:461-9. doi:10.1182/ blood-2007-09-077438

8. Cooper MA, Fehniger TA, Caligiuri MA. The biology of human natural killercell subsets. Trends Immunol (2001) 22:633-40. doi:10.1016/S1471-4906(01) 02060-9

9. Borrego F. The CD300 molecules: an emerging family of regulators of the immune system. Blood (2013) 121:1951-60. doi:10.1182/blood-2012-09435057

10. Borrego F, Kabat J, Kim DK, Lieto L, Maasho K, Pena J, et al. Structure and function of major histocompatibility complex (MHC) class I specific receptors expressed on human natural killer (NK) cells. Mol Immunol (2002) 38:637-60. doi:10.1016/S0161-5890(01)00107-9

11. Lanier LL. Up on the tightrope: natural killer cell activation and inhibition. Nat Immunol (2008) 9:495-502. doi:10.1038/ni1581

12. Long EO, Kim HS, Liu D, Peterson ME, Rajagopalan S. Controlling natural killer cell responses: integration of signals for activation and inhibition. Annu Rev Immunol (2013) 31:227-58. doi:10.1146/annurev-immunol-020711-075005

13. Montaldo E, Del Zotto G, Della Chiesa M, Mingari MC, Moretta A, De Maria A, et al. Human NK cell receptors/markers: a tool to analyze NK cell development, subsets and function. Cytometry A (2013) 83:702-13. doi:10.1002/cyto.a.22302

14. Horst D, Verweij MC, Davison AJ, Ressing ME, Wiertz EJ. Viral evasion of T cell immunity: ancient mechanisms offering new applications. Curr Opin Immunol (2011) 23:96-103. doi:10.1016/j.coi.2010.11.005

15. Karre K, Ljunggren HG, Piontek G, Kiessling R. Selective rejection of H-2deficient lymphoma variants suggests alternative immune defence strategy. Nature (1986) 319:675-8. doi:10.1038/319675a0

16. Hayakawa Y, Smyth MJ. Innate immune recognition and suppression of tumors. Adv Cancer Res (2006) 95:293-322. doi:10.1016/S0065-230X(06) 95008-8

17. Kim S, Iizuka K, Aguila HL, Weissman IL, Yokoyama WM. In vivo natural killer cell activities revealed by natural killer cell-deficient mice. Proc Natl Acad Sci U S A (2000) 97:2731-6. doi:10.1073/pnas.050588297

18. Ljunggren HG, Malmberg KJ. Prospects for the use of NK cells in immunotherapy of human cancer. Nat Rev Immunol (2007) 7:329-39. doi:10.1038/nri2073

19. Wu J, Lanier LL. Natural killer cells and cancer. Adv Cancer Res (2003) 90:127-56. doi:10.1016/S0065-230X(03)90004-2

20. Chretien AS, Le Roy A, Vey N, Prebet T, Blaise D, Fauriat C, et al. Cancer-induced alterations of NK-mediated target recognition: current and 
investigational pharmacological strategies aiming at restoring NK-mediated anti-tumor activity. Front Immunol (2014) 5:122. doi:10.3389/fimmu.2014. 00122

21. Flavell RA, Sanjabi S, Wrzesinski SH, Licona-Limon P. The polarization of immune cells in the tumour environment by TGFbeta. Nat Rev Immunol (2010) 10:554-67. doi:10.1038/nri2808

22. Ma X, Holt D, Kundu N, Reader J, Goloubeva O, Take Y, et al. A prostaglandin E (PGE) receptor EP4 antagonist protects natural killer cells from PGE-mediated immunosuppression and inhibits breast cancer metastasis. Oncoimmunology (2013) 2:e22647. doi:10.4161/onci.22647

23. Salih HR, Goehlsdorf D, Steinle A. Release of MICB molecules by tumor cells: mechanism and soluble MICB in sera of cancer patients. Hum Immunol (2006) 67:188-95. doi:10.1016/j.humimm.2006.02.008

24. Wang D, Saga Y, Mizukami H, Sato N, Nonaka H, Fujiwara H, et al. Indoleamine-2,3-dioxygenase, an immunosuppressive enzyme that inhibits natural killer cell function, as a useful target for ovarian cancer therapy. Int J Oncol (2012) 40:929-34. doi:10.3892/ijo.2011.1295

25. Ames E, Murphy WJ. Advantages and clinical applications of natural killer cells in cancer immunotherapy. Cancer Immunol Immunother (2014) 63:21-8. doi:10.1007/s00262-013-1469-8

26. Cheng M, Chen Y, Xiao W, Sun R, Tian Z. NK cell-based immunotherapy for malignant diseases. Cell Mol Immunol (2013) 10:230-52. doi:10.1038/cmi. 2013.10

27. Terme M, Ullrich E, Delahaye NF, Chaput N, Zitvogel L. Natural killer celldirected therapies: moving from unexpected results to successful strategies. Nat Immunol (2008) 9:486-94. doi:10.1038/ni1580

28. Iannello A, Ahmad A. Role of antibody-dependent cell-mediated cytotoxicity in the efficacy of therapeutic anti-cancer monoclonal antibodies. Cancer Metastasis Rev (2005) 24:487-99. doi:10.1007/s10555-005-6192-2

29. Jiang XR, Song A, Bergelson S, Arroll T, Parekh B, May K, et al. Advances in the assessment and control of the effector functions of therapeutic antibodies. Nat Rev Drug Discov (2011) 10:101-11. doi:10.1038/nrd3365

30. Tarek N, Le Luduec JB, Gallagher MM, Zheng J, Venstrom JM, Chamberlain E, et al. Unlicensed NK cells target neuroblastoma following anti-GD2 antibody treatment. J Clin Invest (2012) 122:3260-70. doi:10.1172/JCI62749

31. Zhou Q, Gil-Krzewska A, Peruzzi G, Borrego F. Matrix metalloproteinases inhibition promotes the polyfunctionality of human natural killer cells in therapeutic antibody-based anti-tumour immunotherapy. Clin Exp Immunol (2013) 173:131-9. doi:10.1111/cei.12095

32. Boiardi A, Silvani A, Ruffini PA, Rivoltini L, Parmiani G, Broggi G, et al. Loco-regional immunotherapy with recombinant interleukin-2 and adherent lymphokine-activated killer cells (A-LAK) in recurrent glioblastoma patients. Cancer Immunol Immunother (1994) 39:193-7. doi:10.1007/BF01533386

33. Cheng M, Zhang J, Jiang W, Chen Y, Tian Z. Natural killer cell lines in tumor immunotherapy. Front Med (2012) 6:56-66. doi:10.1007/s11684-012-0177-7

34. Chouaib S, Pittari G, Nanbakhsh A, El Ayoubi H, Amsellem S, Bourhis JH, et al. Improving the outcome of leukemia by natural killer cell-based immunotherapeutic strategies. Front Immunol (2014) 5:95. doi:10.3389/fimmu.2014.00095

35. Escudier B, Farace F, Angevin E, Charpentier F, Nitenberg G, Triebel F, et al. Immunotherapy with interleukin-2 (IL2) and lymphokine-activated natural killer cells: improvement of clinical responses in metastatic renal cell carcinoma patients previously treated with IL2. Eur J Cancer (1994) 30A:1078-83. doi:10.1016/0959-8049(94)90460-X

36. Iliopoulou EG, Kountourakis P, Karamouzis MV, Doufexis D, Ardavanis A, Baxevanis $\mathrm{CN}$, et al. A phase I trial of adoptive transfer of allogeneic natural killer cells in patients with advanced non-small cell lung cancer. Cancer Immunol Immunother (2010) 59:1781-9. doi:10.1007/s00262-010-0904-3

37. Ishikawa E, Tsuboi K, Saijo K, Harada H, Takano S, Nose T, et al. Autologous natural killer cell therapy for human recurrent malignant glioma. Anticancer Res (2004) 24:1861-71.

38. Miller JS, Soignier Y, Panoskaltsis-Mortari A, McNearney SA, Yun GH, Fautsch SK, et al. Successful adoptive transfer and in vivo expansion of human haploidentical NK cells in patients with cancer. Blood (2005) 105:3051-7. doi:10.1182/blood-2004-07-2974

39. Miller JS, Tessmer-Tuck J, Pierson BA, Weisdorf D, McGlave P, Blazar BR, et al. Low dose subcutaneous interleukin-2 after autologous transplantation generates sustained in vivo natural killer cell activity. Biol Blood Marrow Transplant (1997) 3:34-44.
40. Smyth MJ, Cretney E, Kershaw MH, Hayakawa Y. Cytokines in cancer immunity and immunotherapy. Immunol Rev (2004) 202:275-93. doi:10.1111/j.01052896.2004.00199.x

41. Tonn T, Schwabe D, Klingemann HG, Becker S, Esser R, Koehl U, et al. Treatment of patients with advanced cancer with the natural killer cell line NK-92. Cytotherapy (2013) 15:1563-70. doi:10.1016/j.jcyt.2013.06.017

42. Imai $C$, Iwamoto $S$, Campana D. Genetic modification of primary natural killer cells overcomes inhibitory signals and induces specific killing of leukemic cells. Blood (2005) 106:376-83. doi:10.1182/blood-2004-12-4797

43. Muller T, Uherek C, Maki G, Chow KU, Schimpf A, Klingemann HG, et al. Expression of a CD20-specific chimeric antigen receptor enhances cytotoxic activity of NK cells and overcomes NK-resistance of lymphoma and leukemia cells. Cancer Immunol Immunother (2008) 57:411-23. doi:10.1007/s00262007-0383-3

44. Zhang J, Sun R, Wei H, Zhang J, Tian Z. Characterization of interleukin-15 gene-modified human natural killer cells: implications for adoptive cellular immunotherapy. Haematologica (2004) 89:338-47.

45. Rubnitz JE, Inaba H, Ribeiro RC, Pounds S, Rooney B, Bell T, et al. NKAML: a pilot study to determine the safety and feasibility of haploidentical natural killer cell transplantation in childhood acute myeloid leukemia. J Clin Oncol (2010) 28:955-9. doi:10.1200/JCO.2009.24.4590

46. Verneris MR, Grupp SA. Natural killer cell consolidation for acute myelogenous leukemia: a cell therapy ready for prime time? J Clin Oncol (2010) 28:909-10. doi:10.1200/JCO.2009.26.4002

47. Atkins MB, Kunkel L, Sznol M, Rosenberg SA. High-dose recombinant interleukin-2 therapy in patients with metastatic melanoma: long-term survival update. Cancer J Sci Am (2000) 6(Suppl 1):S11-4.

48. Atkins MB, Lotze MT, Dutcher JP, Fisher RI, Weiss G, Margolin K, et al. Highdose recombinant interleukin 2 therapy for patients with metastatic melanoma: analysis of 270 patients treated between 1985 and 1993. J Clin Oncol (1999) 17:2105-16.

49. Fisher RI, Rosenberg SA, Fyfe G. Long-term survival update for high-dose recombinant interleukin-2 in patients with renal cell carcinoma. Cancer J Sci Am (2000) 6(Suppl 1):S55-7.

50. Krause SW, Gastpar R, Andreesen R, Gross C, Ullrich H, Thonigs G, et al. Treatment of colon and lung cancer patients with ex vivo heat shock protein 70-peptide-activated, autologous natural killer cells: a clinical phase I trial. Clin Cancer Res (2004) 10:3699-707. doi:10.1158/1078-0432.CCR-03-0683

51. Parkhurst MR, Riley JP, Dudley ME, Rosenberg SA. Adoptive transfer of autologous natural killer cells leads to high levels of circulating natural killer cells but does not mediate tumor regression. Clin Cancer Res (2011) 17:6287-97. doi:10.1158/1078-0432.CCR-11-1347

52. Rosenberg SA, Lotze MT, Muul LM, Leitman S, Chang AE, Ettinghausen $\mathrm{SE}$, et al. Observations on the systemic administration of autologous lymphokine-activated killer cells and recombinant interleukin-2 to patients with metastatic cancer. N Engl J Med (1985) 313:1485-92. doi:10.1056/ NEJM198512053132327

53. Rosenberg SA, Yannelli JR, Yang JC, Topalian SL, Schwartzentruber DJ, Weber JS, et al. Treatment of patients with metastatic melanoma with autologous tumor-infiltrating lymphocytes and interleukin 2. J Natl Cancer Inst (1994) 86:1159-66. doi:10.1093/jnci/86.15.1159

54. Ma C, Armstrong AW. Severe adverse events from the treatment of advanced melanoma: a systematic review of severe side effects associated with ipilimumab, vemurafenib, interferon alfa-2b, dacarbazine and interleukin-2. J Dermatolog Treat (2014) 25:401-8. doi:10.3109/09546634.2013.813897

55. Ralainirina N, Poli A, Michel T, Poos L, Andres E, Hentges F, et al. Control of NK cell functions by CD4+CD25+ regulatory T cells. J Leukoc Biol (2007) 81:144-53. doi:10.1189/jlb.0606409

56. Burns LJ, Weisdorf DJ, DeFor TE, Vesole DH, Repka TL, Blazar BR, et al. IL-2-based immunotherapy after autologous transplantation for lymphoma and breast cancer induces immune activation and cytokine release: a phase I/II trial. Bone Marrow Transplant (2003) 32:177-86. doi:10.1038/sj.bmt. 1704086

57. Ruggeri L, Capanni M, Casucci M, Volpi I, Tosti A, Perruccio K, et al. Role of natural killer cell alloreactivity in HLA-mismatched hematopoietic stem cell transplantation. Blood (1999) 94:333-9.

58. Ruggeri L, Capanni M, Urbani E, Perruccio K, Shlomchik WD, Tosti A, et al. Effectiveness of donor natural killer cell alloreactivity in mismatched 
hematopoietic transplants. Science (2002) 295:2097-100. doi:10.1126/science. 1068440

59. Pende D, Marcenaro S, Falco M, Martini S, Bernardo ME, Montagna D, et al. Anti-leukemia activity of alloreactive NK cells in KIR ligand-mismatched haploidentical HSCT for pediatric patients: evaluation of the functional role of activating KIR and redefinition of inhibitory KIR specificity. Blood (2009) 113:3119-29. doi:10.1182/blood-2008-06-164103

60. Ruggeri L, Mancusi A, Capanni M, Urbani E, Carotti A, Aloisi T, et al. Donor natural killer cell allorecognition of missing self in haploidentical hematopoietic transplantation for acute myeloid leukemia: challenging its predictive value. Blood (2007) 110:433-40. doi:10.1182/blood-2006-07-038687

61. Venstrom JM, Pittari G, Gooley TA, Chewning JH, Spellman S, Haagenson M, et al. HLA-C-dependent prevention of leukemia relapse by donor activating KIR2DS1. N Engl J Med (2012) 367:805-16. doi:10.1056/NEJMoa1200503

62. Willemze R, Rodrigues CA, Labopin M, Sanz G, Michel G, Socie G, et al. KIRligand incompatibility in the graft-versus-host direction improves outcomes after umbilical cord blood transplantation for acute leukemia. Leukemia (2009) 23:492-500. doi:10.1038/leu.2008.365

63. Curti A, Ruggeri L, D’Addio A, Bontadini A, Dan E, Motta MR, et al. Successful transfer of alloreactive haploidentical KIR ligand-mismatched natural killer cells after infusion in elderly high risk acute myeloid leukemia patients. Blood (2011) 118:3273-9. doi:10.1182/blood-2011-01-329508

64. Geller MA, Cooley S, Judson PL, Ghebre R, Carson LF, Argenta PA, et al. A phase II study of allogeneic natural killer cell therapy to treat patients with recurrent ovarian and breast cancer. Cytotherapy (2011) 13:98-107. doi:10.3109/14653249.2010.515582

65. Geller MA, Miller JS. Use of allogeneic NK cells for cancer immunotherapy. Immunotherapy (2011) 3:1445-59. doi:10.2217/imt.11.131

66. Rizzieri DA, Storms R, Chen DF, Long G, Yang Y, Nikcevich DA, et al. Natural killer cell-enriched donor lymphocyte infusions from A 3-6/6 HLA matched family member following nonmyeloablative allogeneic stem cell transplantation. Biol Blood Marrow Transplant (2010) 16:1107-14. doi:10.1016/j.bbmt. 2010.02.018

67. Stern M, Passweg JR, Meyer-Monard S, Esser R, Tonn T, Soerensen J, et al. Pre-emptive immunotherapy with purified natural killer cells after haploidentical SCT: a prospective phase II study in two centers. Bone Marrow Transplant (2013) 48:433-8. doi:10.1038/bmt.2012.162

68. Arai S, Meagher R, Swearingen M, Myint H, Rich E, Martinson J, et al. Infusion of the allogeneic cell line NK-92 in patients with advanced renal cell cancer or melanoma: a phase I trial. Cytotherapy (2008) 10:625-32. doi:10.1080/14653240802301872

69. Tam YK, Martinson JA, Doligosa K, Klingemann HG. Ex vivo expansion of the highly cytotoxic human natural killer-92 cell-line under current good manufacturing practice conditions for clinical adoptive cellular immunotherapy. Cytotherapy (2003) 5:259-72. doi:10.1080/14653240310001523

70. Altvater B, Landmeier S, Pscherer S, Temme J, Schweer K, Kailayangiri S, et al. 2B4 (CD244) signaling by recombinant antigen-specific chimeric receptors costimulates natural killer cell activation to leukemia and neuroblastoma cells. Clin Cancer Res (2009) 15:4857-66. doi:10.1158/1078-0432.CCR-082810

71. Boissel L, Betancur M, Lu W, Wels WS, Marino T, Van Etten RA, et al. Comparison of mRNA and lentiviral based transfection of natural killer cells with chimeric antigen receptors recognizing lymphoid antigens. Leuk Lymphoma (2012) 53:958-65. doi:10.3109/10428194.2011.634048

72. Boissel L, Betancur M, Wels WS, Tuncer H, Klingemann H. Transfection with mRNA for CD19 specific chimeric antigen receptor restores NK cell mediated killing of CLL cells. Leuk Res (2009) 33:1255-9. doi:10.1016/j.leukres.2008. 11.024

73. Boissel L, Betancur-Boissel M, Lu W, Krause DS, Van Etten RA, Wels WS, et al. Retargeting NK-92 cells by means of CD19- and CD20-specific chimeric antigen receptors compares favorably with antibody-dependent cellular cytotoxicity. Oncoimmunology (2013) 2:e26527. doi:10.4161/onci.26527

74. Chu J, Deng Y, Benson DM, He S, Hughes T, Zhang J, et al. CS1-specific chimeric antigen receptor (CAR)-engineered natural killer cells enhance in vitro and in vivo antitumor activity against human multiple myeloma. Leukemia (2014) 28:917-27. doi:10.1038/leu.2013.279

75. Esser R, Muller T, Stefes D, Kloess S, Seidel D, Gillies SD, et al. NK cells engineered to express a GD2-specific antigen receptor display built-in ADCC-like activity against tumour cells of neuroectodermal origin. J Cell Mol Med (2012) 16:569-81. doi:10.1111/j.1582-4934.2011.01343.x

76. Jiang H, Zhang W, Shang P, Zhang H, Fu W, Ye F, et al. Transfection of chimeric anti-CD138 gene enhances natural killer cell activation and killing of multiple myeloma cells. Mol Oncol (2014) 8:297-310. doi:10.1016/j.molonc. 2013.12.001

77. Oberoi P, Wels WS. Arming NK cells with enhanced antitumor activity: CARs and beyond. Oncoimmunology (2013) 2:e25220. doi:10.4161/onci.25220

78. Sahm C, Schonfeld K, Wels WS. Expression of IL-15 in NK cells results in rapid enrichment and selective cytotoxicity of gene-modified effectors that carry a tumor-specific antigen receptor. Cancer Immunol Immunother (2012) 61:1451-61. doi:10.1007/s00262-012-1212-x

79. Uherek C, Tonn T, Uherek B, Becker S, Schnierle B, Klingemann HG, et al. Retargeting of natural killer-cell cytolytic activity to ErbB2-expressing cancer cells results in efficient and selective tumor cell destruction. Blood (2002) 100:1265-73.

80. Bachanova V, Cooley S, Defor TE, Verneris MR, Zhang B, McKenna DH, et al. Clearance of acute myeloid leukemia by haploidentical natural killer cells is improved using IL-2 diphtheria toxin fusion protein. Blood (2014) 123:3855-63. doi:10.1182/blood-2013-10-532531

81. Killig M, Friedrichs B, Meisig J, Gentilini C, Bluthgen N, Loddenkemper C, et al. Tracking in vivo dynamics of NK cells transferred in patients undergoing stem cell transplantation. Eur J Immunol (2014). doi:10.1002/eji.201444586

82. Bethge WA, Faul C, Bornhauser M, Stuhler G, Beelen DW, Lang P, et al. Haploidentical allogeneic hematopoietic cell transplantation in adults using CD3/CD19 depletion and reduced intensity conditioning: an update. Blood Cells Mol Dis (2008) 40:13-9. doi:10.1016/j.bcmd.2007.07.001

83. Berg M, Lundqvist A, McCoy P Jr, Samsel L, Fan Y, Tawab A, et al. Clinical-grade ex vivo-expanded human natural killer cells up-regulate activating receptors and death receptor ligands and have enhanced cytolytic activity against tumor cells. Cytotherapy (2009) 11:341-55. doi:10.1080/14653240902807034

84. Koehl U, Brehm C, Huenecke S, Zimmermann SY, Kloess S, Bremm M, et al. Clinical grade purification and expansion of NK cell products for an optimized manufacturing protocol. Front Oncol (2013) 3:118. doi:10.3389/fonc. 2013.00118

85. Koepsell SA, Miller JS, McKenna DH Jr. Natural killer cells: a review of manufacturing and clinical utility. Transfusion (2013) 53:404-10. doi:10.1111/j. 1537-2995.2012.03724.x

86. Lapteva N, Durett AG, Sun J, Rollins LA, Huye LL, Fang J, et al. Large-scale ex vivo expansion and characterization of natural killer cells for clinical applications. Cytotherapy (2012) 14:1131-43. doi:10.3109/14653249.2012.700767

87. Lim O, Lee Y, Chung H, Her JH, Kang SM, Jung MY, et al. GMP-compliant, large-scale expanded allogeneic natural killer cells have potent cytolytic activity against cancer cells in vitro and in vivo. PLoS One (2013) 8:e53611. doi:10.1371/journal.pone.0053611

88. Luevano M, Domogala A, Blundell M, Jackson N, Pedroza-Pacheco I, Derniame $\mathrm{S}$, et al. Frozen cord blood hematopoietic stem cells differentiate into higher numbers of functional natural killer cells in vitro than mobilized hematopoietic stem cells or freshly isolated cord blood hematopoietic stem cells. PLoS One (2014) 9:e87086. doi:10.1371/journal.pone.0087086

89. Luevano M, Madrigal A, Saudemont A. Generation of natural killer cells from hematopoietic stem cells in vitro for immunotherapy. Cell Mol Immunol (2012) 9:310-20. doi:10.1038/cmi.2012.17

90. Siegler U, Meyer-Monard S, Jorger S, Stern M, Tichelli A, Gratwohl A, et al. Good manufacturing practice-compliant cell sorting and large-scale expansion of single KIR-positive alloreactive human natural killer cells for multiple infusions to leukemia patients. Cytotherapy (2010) 12:750-63. doi:10.3109/ 14653241003786155

91. Spanholtz J, Preijers F, Tordoir M, Trilsbeek C, Paardekooper J, de Witte T, et al. Clinical-grade generation of active NK cells from cord blood hematopoietic progenitor cells for immunotherapy using a closed-system culture process. PLoS One (2011) 6:e20740. doi:10.1371/journal.pone.0020740

92. Spanholtz J, Tordoir M, Eissens D, Preijers F, van der Meer A, Joosten I, et al. High log-scale expansion of functional human natural killer cells from umbilical cord blood CD34-positive cells for adoptive cancer immunotherapy. PLoS One (2010) 5:e9221. doi:10.1371/journal.pone.0009221

93. Lehmann D, Spanholtz J, Sturtzel C, Tordoir M, Schlechta B, Groenewegen $\mathrm{D}$, et al. IL-12 directs further maturation of ex vivo differentiated NK cells 
with improved therapeutic potential. PLoS One (2014) 9:e87131. doi:10.1371/ journal.pone.0087131

94. Sutlu T, Stellan B, Gilljam M, Quezada HC, Nahi H, Gahrton G, et al. Clinicalgrade, large-scale, feeder-free expansion of highly active human natural killer cells for adoptive immunotherapy using an automated bioreactor. Cytotherapy (2010) 12:1044-55. doi:10.3109/14653249.2010.504770

95. Dezell SA, Ahn YO, Spanholtz J, Wang H, Weeres M, Jackson S, et al. Natural killer cell differentiation from hematopoietic stem cells: a comparative analysis of heparin- and stromal cell-supported methods. Biol Blood Marrow Transplant (2012) 18:536-45. doi:10.1016/j.bbmt.2011.11.023

96. Cany J, van der Waart AB, Tordoir M, Franssen GM, Hangalapura BN, de Vries J, et al. Natural killer cells generated from cord blood hematopoietic progenitor cells efficiently target bone marrow-residing human leukemia cells in NOD/SCID/IL2Rg(null) mice. PLoS One (2013) 8:e64384. doi:10.1371/ journal.pone. 0064384

97. Pinho MJ, Punzel M, Sousa M, Barros A. Ex vivo differentiation of natural killer cells from human umbilical cord blood CD34+ progenitor cells. Cell Commun Adhes (2011) 18:45-55. doi:10.3109/15419061.2011.610911

98. Frias AM, Porada CD, Crapnell KB, Cabral JM, Zanjani ED, Almeida-Porada G. Generation of functional natural killer and dendritic cells in a human stromalbased serum-free culture system designed for cord blood expansion. Exp Hematol (2008) 36:61-8. doi:10.1016/j.exphem.2007.08.031

99. Bock AM, Knorr D, Kaufman DS. Development, expansion, and in vivo monitoring of human NK cells from human embryonic stem cells (hESCs) and induced pluripotent stem cells (iPSCs). J Vis Exp (2013) (74):e50337. doi:10.3791/50337

100. Knorr DA, Ni Z, Hermanson D, Hexum MK, Bendzick L, Cooper LJ, et al. Clinical-scale derivation of natural killer cells from human pluripotent stem cells for cancer therapy. Stem Cells Transl Med (2013) 2:274-83. doi:10.5966/ sctm.2012-0084

101. Larbi A, Gombert JM, Auvray C, l'Homme B, Magniez A, Feraud O, et al. The HOXB4 homeoprotein promotes the ex vivo enrichment of functional human embryonic stem cell-derived NK cells. PLoS One (2012) 7:e39514. doi:10.1371/journal.pone.0039514

102. Ni Z, Knorr DA, Kaufman DS. Hematopoietic and nature killer cell development from human pluripotent stem cells. Methods Mol Biol (2013) 1029:33-41. doi:10.1007/978-1-62703-478-4_3

103. Woll PS, Grzywacz B, Tian X, Marcus RK, Knorr DA, Verneris MR, et al. Human embryonic stem cells differentiate into a homogeneous population of natural killer cells with potent in vivo antitumor activity. Blood (2009) 113:6094-101. doi:10.1182/blood-2008-06-165225

104. Woll PS, Martin CH, Miller JS, Kaufman DS. Human embryonic stem cellderived NK cells acquire functional receptors and cytolytic activity. J Immunol (2005) 175:5095-103. doi:10.4049/jimmunol.175.8.5095

105. Thomson JA, Itskovitz-Eldor J, Shapiro SS, Waknitz MA, Swiergiel JJ, Marshall VS, et al. Embryonic stem cell lines derived from human blastocysts. Science (1998) 282:1145-7. doi:10.1126/science.282.5391.1145

106. Choi KD, Vodyanik MA, Slukvin II. Generation of mature human myelomonocytic cells through expansion and differentiation of pluripotent stem cell-derived lin-CD $34+C D 43+C D 45+$ progenitors. J Clin Invest (2009) 119:2818-29. doi:10.1172/JCI38591

107. Galic Z, Kitchen SG, Kacena A, Subramanian A, Burke B, Cortado R, et al. T lineage differentiation from human embryonic stem cells. Proc Natl Acad Sci U $S$ A (2006) 103:11742-7. doi:10.1073/pnas.0604244103

108. Kaufman DS. Toward clinical therapies using hematopoietic cells derived from human pluripotent stem cells. Blood (2009) 114:3513-23. doi:10.1182/blood2009-03-191304

109. Kaufman DS, Hanson ET, Lewis RL, Auerbach R, Thomson JA. Hematopoietic colony-forming cells derived from human embryonic stem cells. Proc Natl Acad Sci U S A (2001) 98:10716-21. doi:10.1073/pnas.191362598

110. Ledran MH, Krassowska A, Armstrong L, Dimmick I, Renstrom J, Lang R, et al. Efficient hematopoietic differentiation of human embryonic stem cells on stromal cells derived from hematopoietic niches. Cell Stem Cell (2008) 3:85-98. doi:10.1016/j.stem.2008.06.001

111. Vodyanik MA, Bork JA, Thomson JA, Slukvin II. Human embryonic stem cellderived CD34+ cells: efficient production in the coculture with OP9 stromal cells and analysis of lymphohematopoietic potential. Blood (2005) 105:617-26. doi:10.1182/blood-2004-04-1649
112. Eguizabal C, Montserrat N, Vassena R, Barragan M, Garreta E, Garcia-Quevedo $\mathrm{L}$, et al. Complete meiosis from human induced pluripotent stem cells. Stem Cells (2011) 29:1186-95. doi:10.1002/stem.672

113. Takahashi K, Tanabe K, Ohnuki M, Narita M, Ichisaka T, Tomoda K, et al. Induction of pluripotent stem cells from adult human fibroblasts by defined factors. Cell (2007) 131:861-72. doi:10.1016/j.cell.2007.11.019

114. Takahashi K, Yamanaka S. Induction of pluripotent stem cells from mouse embryonic and adult fibroblast cultures by defined factors. Cell (2006) 126:663-76. doi:10.1016/j.cell.2006.07.024

115. Gonzalez F, Barragan Monasterio M, Tiscornia G, Montserrat Pulido N, Vassena R, Batlle Morera L, et al. Generation of mouse-induced pluripotent stem cells by transient expression of a single nonviral polycistronic vector. Proc Natl Acad Sci U S A (2009) 106:8918-22. doi:10.1073/pnas.0901471106

116. Aasen T, Raya A, Barrero MJ, Garreta E, Consiglio A, Gonzalez F, et al. Efficient and rapid generation of induced pluripotent stem cells from human keratinocytes. Nat Biotechnol (2008) 26:1276-84. doi:10.1038/nbt.1503

117. Giorgetti A, Montserrat N, Aasen T, Gonzalez F, Rodriguez-Piza I, Vassena R, et al. Generation of induced pluripotent stem cells from human cord blood using OCT4 and SOX2. Cell Stem Cell (2009) 5:353-7. doi:10.1016/j.stem. 2009.09.008

118. Feldman N, Gerson A, Fang J, Li E, Zhang Y, Shinkai Y, et al. G9a-mediated irreversible epigenetic inactivation of Oct-3/4 during early embryogenesis. Nat Cell Biol (2006) 8:188-94. doi:10.1038/ncb1353

119. Huangfu D, Maehr R, Guo W, Eijkelenboom A, Snitow M, Chen AE, et al. Induction of pluripotent stem cells by defined factors is greatly improved by smallmolecule compounds. Nat Biotechnol (2008) 26:795-7. doi:10.1038/nbt1418

120. Huangfu D, Osafune K, Maehr R, Guo W, Eijkelenboom A, Chen S, et al. Induction of pluripotent stem cells from primary human fibroblasts with only Oct4 and Sox2. Nat Biotechnol (2008) 26:1269-75. doi:10.1038/nbt.1502

121. Li W, Zhou H, Abujarour R, Zhu S, Young Joo J, Lin T, et al. Generation of human-induced pluripotent stem cells in the absence of exogenous Sox2. Stem Cells (2009) 27:2992-3000. doi:10.1002/stem.240

122. Shi Y, Desponts C, Do JT, Hahm HS, Scholer HR, Ding S. Induction of pluripotent stem cells from mouse embryonic fibroblasts by Oct 4 and Klf4 with smallmolecule compounds. Cell Stem Cell (2008) 3:568-74. doi:10.1016/j.stem.2008. 10.004

123. Gonzalez F, Boue S, Izpisua Belmonte JC. Methods for making induced pluripotent stem cells: reprogramming a la carte. Nat Rev Genet (2011) 12:231-42. doi:10.1038/nrg2937

124. Eguizabal C, Montserrat N, Veiga A, Izpisua Belmonte JC. Dedifferentiation, transdifferentiation, and reprogramming: future directions in regenerative medicine. Semin Reprod Med (2013) 31:82-94. doi:10.1055/s-0032- 1331802

125. Araki R, Uda M, Hoki Y, Sunayama M, Nakamura M, Ando S, et al. Negligible immunogenicity of terminally differentiated cells derived from induced pluripotent or embryonic stem cells. Nature (2013) 494:100-4. doi:10.1038/ nature 11807

126. Cao J, Li X, Lu X, Zhang C, Yu H, Zhao T. Cells derived from iPSC can be immunogenic - yes or no? Protein Cell (2014) 5:1-3. doi:10.1007/s13238-0130003-2

127. Guha P, Morgan JW, Mostoslavsky G, Rodrigues NP, Boyd AS. Lack of immune response to differentiated cells derived from syngeneic induced pluripotent stem cells. Cell Stem Cell (2013) 12:407-12. doi:10.1016/j.stem.2013.01.006

128. Zhao T, Zhang ZN, Rong Z, Xu Y. Immunogenicity of induced pluripotent stem cells. Nature (2011) 474:212-5. doi:10.1038/nature10135

129. Raya A, Rodriguez-Piza I, Guenechea G, Vassena R, Navarro S, Barrero MJ, et al. Disease-corrected haematopoietic progenitors from Fanconi anaemia induced pluripotent stem cells. Nature (2009) 460:53-9. doi:10.1038/nature08129

130. Knorr DA, Bock A, Brentjens RJ, Kaufman DS. Engineered human embryonic stem cell-derived lymphocytes to study in vivo trafficking and immunotherapy. Stem Cells Dev (2013) 22:1861-9. doi:10.1089/scd.2012.0608

131. Ni Z, Knorr DA, Clouser CL, Hexum MK, Southern P, Mansky LM, et al. Human pluripotent stem cells produce natural killer cells that mediate antiHIV-1 activity by utilizing diverse cellular mechanisms. JVirol (2011) 85:43-50. doi:10.1128/JVI.01774-10

132. Woll PS, Morris JK, Painschab MS, Marcus RK, Kohn AD, Biechele TL, et al. Wnt signaling promotes hematoendothelial cell development from human embryonic stem cells. Blood (2008) 111:122-31. doi:10.1182/blood-2007-04084186 
133. Tabatabaei-Zavareh N, Vlasova A, Greenwood CP, Takei F. Characterization of developmental pathway of natural killer cells from embryonic stem cells in vitro. PLoS One (2007) 2:e232. doi:10.1371/journal.pone.0000232

Conflict of Interest Statement: The authors declare that the research was conducted in the absence of any commercial or financial relationships that could be construed as a potential conflict of interest.

Received: 13 June 2014; accepted: 29 August 2014; published online: 15 September 2014. Citation: Eguizabal C, Zenarruzabeitia O, Monge J, Santos S, Vesga MA, Maruri $N$, Arrieta A, Riñón M, Tamayo-Orbegozo E, Amo L, Larrucea $S$ and Borrego $F$
(2014) Natural killer cells for cancer immunotherapy: pluripotent stem cellsderived NK cells as an immunotherapeutic perspective. Front. Immunol. 5:439. doi: 10.3389/fimmu.2014.00439

This article was submitted to NK Cell Biology, a section of the journal Frontiers in Immunology.

Copyright (C) 2014 Eguizabal, Zenarruzabeitia, Monge, Santos, Vesga, Maruri, Arrieta, Riñón, Tamayo-Orbegozo, Amo, Larrucea and Borrego. This is an open-access article distributed under the terms of the Creative Commons Attribution License (CC BY). The use, distribution or reproduction in other forums is permitted, provided the original author(s) or licensor are credited and that the original publication in this journal is cited, in accordance with accepted academic practice. No use, distribution or reproduction is permitted which does not comply with these terms. 